УДК 81,81 '33, 811.161.1

DOI: $10.17223 / 22274200 / 10 / 2$

\title{
М.В. Грекова
}

\section{ФИГУРАТИВНАЯ ЛЕКСИКОГРАФИЯ И ЕЕ МЕСТО В СОВРЕМЕННОЙ РУСИСТИКЕ}

\begin{abstract}
В статье рассматриваются различные словари образных слов и выражений русского языка, составляющие особое направление русистики, которое обозначено термином «фигуративная лексикография». Разнообразные по целям $и$ структуре словари объединены общим объектом описания, в качестве которого выступают лексические, паремиологические и фразеологические единииы, иносказательно выражающие представления о называемых объектах и составляющие образный фонд русского языка. Выявляются принщипы фигуративной лексикографии, которые до последнего времени не рефлексировались как определённая программа лексикографического исследования образного словарного фонда, но были реализованы в практике создания словарей, описываюших различные фрагменты лексической, паремиологической и фразеологической репрезентации образной системы.

Ключевые слова: фигуративная лексикография, лингвокультурологический словарь, образная лексика, фразеология, пищевая метафора.
\end{abstract} 【елью данной статьи является определение состава, объёма, бого направления русистики 2 , посвященного созданию словарей, описывающих вторичные номинации с образным значением. Эта цель обусловлена необходимостью решения ряда задач прикладного характера, связанных с практической работой по созданию «Словаря русской пищевой метафоры»[1], первый том которого «Блюда и продукты питания» уже вышел в свет, второй том «Гастрономическая деятельность» подготовлен к печати; однако многие проблемы концептуальной организации материала и его семантизации требуют теоретического осмысления и научного освещения. При разработке концепции данного словаря потребовалось изучить и проанализировать сложившуюся традицию фигуративной лексикографии, выявить принципы и приёмы лексикографирования вторичных образных но-

${ }^{1}$ Исследование выполнено при финансовой поддержке РГНФ. Грант № 1404-00207a - «Русская пищевая традиция в зеркале языковых образов: лингвокультурологическое и лексикографическое описание», 2014-2016 гг.

2 Это направление может быть выделено в любой лексикографии. В данной статье анализируется, как фигуративная лексикография развивается в русистике. 
минаций, обладающих ёмкой двуплановой семантикой, которая включает экспрессивно-оценочный и культурологический компоненты коннотаций. Поэтому задачи, конкретизирующие цель, носят в большей степени теоретический характер: 1) определение корпуса словарей, описывающих образные средства русского языка, анализ способов толкования семантики, особенностей построения микро- и макроструктуры, обусловленных целями лексикографирования; 2) выявление принципов фигуративной лексикографии, которые до последнего времени не рефлексировались как определённая программа лексикографического исследования образного словарного фонда, но при этом были реализованы в практике создания словарей, описывающих различные фрагменты лексической и фразеологической репрезентации образной системы; 3) освещение того, как данные принципы реализованы в «Словаре русской пищевой метафоры» [1], призванном системно отразить образный фонд русского языка, представляющий метафорическую и символическую концептуализацию мира в терминах пищевого кода культуры.

\section{Образные средства языка как объект фигуративной лекси- кографии}

Антропологическая парадигма современного языкознания предполагает изучение языка в его неразрывной связи с человеком и культурой (Н.Ф. Алефиренко, Ю.Д. Апресян, Н.Д. Арутюнова, В.Н. Телия и др.), поскольку человек воспринимает мир опосредованно, через культуру и язык, а язык, в свою очередь, отражает взгляд человека на мир. В связи с этим современные словари ориентируются на выявление и описание фоновых знаний, закреплённых за языковыми единицами: разного рода ассоциаций, коннотаций (экспрессивных, образных, символических, культурологических), социокультурных стереотипов. В современных словарях представлено многоаспектное описание лексикографируемых единиц. Даётся собственно лингвистическая информация, связанная с отражением семантики, стилистики, грамматики, функционирования толкуемых языковых единиц, а также информация культурологического, социологического, психологического характера [2. С. 180]. Следовательно, в задачу лексикографов входит разработка способов оптимальной подачи этой информации; моделирования такой макро- и микроструктуры словаря, которая позволила бы полно, точно и лаконично 
описать языковой материал, а в ряде случаев - представить системность описываемого фрагмента лексико-семантической системы.

Плодотворно развивается в этом направлении лексикографическое описание образных единиц языка. За последние двадцать лет вышли в свет разнообразные словари, описывающие различные фрагменты образной системы языка и демонстрирующие новые подходы к лексикографической презентации языковой образности ([324] и др.). Именно этот фонд словарей мы, вслед за Е.А. Юриной, предлагаем обозначить термином «фигуративная лексикография», в котором определение «фигуративная» является синонимом термину «образная» и восходит к английским «figurativeness» 'образность' и «figurative language» 'образный язык'. Фигуративная лексикография - это особое направление русистики, которое занимается составлением и изучением словарей, лексикографирующих образный строй русского языка. Данный термин также коррелирует с таким понятием, как «фигура речи» 'иносказательное выражение, использующее слова в переносных значениях и несущее экспрессивный стилистический эффект' [1. С. 3]. Объектом фигуративной лексикографии являются разнообразные по целям и структуре словари, объединённые образным характером единиц описания, обладающих метафорической внутренней формой, реализующих иносказательный, фигуральный способ представления мысли или идеи. К числу таких лексикографических трудов можно отнести фразеологические [3-11] и лингвокультурологические словари [1, 12-15], словари образных слов и выражений [16-19], пословиц и поговорок [20, 21], поэтических образов [22, 23], дискурсивных метафор [24].

Под языковой образностью, вслед за Н.Ф. Алефиренко, О.И. Блиновой, Н.А. Илюхиной, М.А. Лукьяновой, Е.А. Юриной и др., понимается свойство лексических, фразеологических, текстовых единиц, проявляющееся в их способности обозначать явление, факт, ситуацию внеязыковой действительности опосредованно, иносказательно, через аналогию с другими фактами, явлениями, основанных на сходстве, смежности, ассоциативном сближении, метафорических и символических культурно обусловленных ассоциациях. Подобное свойство обнаруживается у лексических и фразеологических единиц языка, паремий, текстов тропеического характера, включающих сравнения, метафоры, метафорические эпитеты, олицетворения, которые обладают двуплановой семантикой, образной внутренней 
формой ${ }^{1}$. При этом носители языка осознают нетождественность исходного образного основания и результирующего понятийного содержания образного слова или выражения и наличие культурной коннотации [27. С. 5-8].

Лексикографическое описание образных средств языка традиционно осуществлялось по дифференциальному принципу, когда в одном словаре описывается определённый структурный тип образной единицы. Например, фразеологические словари ориентированы на описание идиом [3-11]; словари образных сравнений включают устойчивые компаративы [19]; словарь образной лексики русского языка описывает языковые метафоры и метафорические дериваты [16]; словари пословиц, поговорок, крылатых фраз - «паремиологический фонд» и «крылатику» [18, 20, 21].

Обширной областью фигуративной лексикографии является фразеография. Со второй половины XX в. до настоящего времени в трудах А.Н. Баранова, А.К. Бириха, Д.О. Добровольского, В.П. Жукова, М.Л. Ковшовой, А.М. Мелерович, В.М. Мокиенко, А.И. Молоткова, Л.И. Степановой, В.Н. Телия, А.И Федорова и др. активно исследуются семантические, грамматические, структурные свойства фразеологических единиц, их происхождение и функционирование в речи. Это способствовало созданию разнообразных фразеологических словарей.

В полном объёме фразеологизмы русского языка были собраны и подробно описаны во «Фразеологическом словаре русского языка» под редакцией А.И. Молоткова [11]. Впервые автором были представлены разнообразные трансформированные употребления фразеологических единиц, ситуации их употребления в речи. Этот словарь долгое время считался основным типом толкового фразеологического словаря современного русского языка. В нём дано свыше 4000 словарных статей. В словаре преобладают устойчивые обороты идиоматического характера. По мнению авторов, фразеологический словарь не только фиксирует образные единицы, но и отражает национальные особенности языка, его самобытность.

За последние двадцать лет появилось более ста специальных фразеологических словарей разных жанров, составленных научными коллективами и представителями научных школ, разработаны от-

${ }^{1}$ Подробно см.: [26. С. 130-138; 2. С. 20-29]. 
дельные принципы лексикографирования образных фразеологических единиц. Московская фразеологическая школа под руководством В.Н. Телия разрабатывает глубокий семантический анализ фразеологизмов с учётом их образной мотивации и культурной коннотации на материале русского и других национальных языков [29]. Первым результатом этой работы стал «Словарь образных выражений русского языка» [17]. Макроструктура данного словаря моделируется по идеографическому принципу и состоит из 16 тематических групп, внутри которых образные выражения расположены в алфавитном порядке. «Большой фразеологический словарь русского языка» под ред. В.Н. Телия [4] не имеет аналогов в российской фразеографии. Толкования фразеологических единиц сопровождаются изъяснением их использования в речевых ситуациях, стилистическими пометами и контекстными иллюстрациями, демонстрирующими все жанры письменной речи. Показаны образно-смысловые гнёзда фразеологизмов в одной, общей для них словарной статье. В данном словаре фразеологизмы представлены как знаки языка культуры и сопровождаются не только лингвистическим толкованием, но и культурологическим комментарием, который эксплицирует культурные смыслы, заложенные во фразеологических единицах.

А.Н. Барановым, Д.О. Добровольским создан «Фразеологический объяснительный словарь русского языка» [3]. Он включает около тысячи идиом современного русского языка и около двух тысяч значений. Толкование идиом раскрывает образную составляющую их семантики - метафору, лежащую в основе значения. Для многих идиом предусмотрены краткие эквиваленты, а также комментарии - информация о происхождении фразеологизмов, описание грамматических особенностей употребления, характерные черты прагматики [3].

В словаре А.М. Мелерович, В.М. Мокиенко «Фразеологизмы в русской речи» [7] были введены разнообразные трансформированные употребления фразеологических единиц, включены индивидуально-авторские употребления фразеологизмов. По мнению составителей словаря, это способствует фиксации реального речевого бытования фразеологизма, описанию его речевых потенций и особенностей его употребления в конкретном языке. В нём впервые представлена полная функционально-семантическая характеристика фразеологических единиц, которая включает подробное истолкование зна- 
чений и различных их употреблений в современном русском литературном языке, выявление основных типов трансформаций и стилистических способов преобразования фразеологизмов в тексте. Фразеологические единицы представлены в словаре в разнообразных контекстах, репрезентирующих типовые ситуации их использования.

В пространство фигуративной лексикографии также включаются словари образных сравнений. Одним из первых в отечественной и зарубежной лексикографии словарей, описывающих около 1500 наиболее употребительных сравнений, является «Словарь устойчивых сравнений русского языка» В.М. Огольцева [19]. Материалом данного словаря стали общенародные (устойчивые) сравнения литературного употребления, являющиеся по происхождению фольклорными или книжными. Данный лексикографический труд составлен на основе специальной картотеки, в которую включено более 60000 цитат из художественных произведений, мемуарных, эпистолярных и публицистических источников периода от А.С. Пушкина до наших дней. В словаре принят алфавитно-гнездовой принцип подачи материала.

Образная лексика долгое время не вычленялась как особый тип единиц лексикона, и её лексикографирование осуществлялось в рамках составления толковых словарей. Системный подход к лексикографированию языковой метафоры оформился в конце 80-х гг. прошлого века и был представлен в работе Г.Н. Скляревской «Языковая метафора в толковом словаре. Проблемы семантики» [30]. В этот период появляются первые словари образных слов, которые также относятся к продуктам фигуративной лексикографии. Впервые образная лексика и фразеология в их единстве были описаны на материале среднеобского диалекта в «Словаре образных слов и выражений сибирского говора» под редакцией О.И. Блиновой (первое издание - 1997 г., второе издание - 2001 г.) [17]. Составители данного словаря с опорой на уже имеющиеся достижения в области лексикографирования языковых метафор $[31,32]$ в толковом словаре разработали структуру словарной статьи с учётом специфики лексикографируемого материала: добавлены пометы культурологической характеристики образного языкового средства. Позднее О.И. Блиновой, Е.А. Юриной был издан «Словарь образных слов русского языка» [16]. Объектом лексикографирования в данном словаре являются 
образные языковые метафоры и собственно образные слова - дериваты с метафорической внутренней формой.

Вместе с тем появляются словари, комплексно описывающие образный лексико-фразеологический и паремиологический фонд в его целостности, обусловленной семантической общностью образов, выраженных в языковых единицах разного структурного типа ${ }^{1}$. Например, «Словарь образных слов и выражений народного говора» под ред. О.И. Блиновой [17] включает языковые метафоры, образные сравнения, идиомы, пословицы и поговорки, свойственные среднеобскому диалекту. В этом случае критерием отбора толкуемых в словаре единиц выступает само свойство образности языкового средства, а не его структурная разновидность. Дифференциация осуществляется на основании наличия / отсутствия образности. Словарь описывает различные образные единицы как лексикофразеологическую подсистему диалекта.

Частью фигуративной лексикографии также является словарное описание образных средств поэтической речи. Система образов художественной речи была представлена в «Словаре поэтических образов» Н.В. Павлович [22], где описаны парадигмы поэтических образов, которые употребляются разными поэтами и писателями на протяжении трёх веков. Кроме того, поэтические образы зафиксированы в «Словаре языка поэзии (образный арсенал русской лирики конца XVIII - начала XX в.)» Н.Н. Ивановой [23], в котором лексикографическому описанию и семантической классификации подверглись следующие типы единиц языка поэзии: описательнометафорические сочетания, перифрастические сочетания, словасимволы. Словарная статья состоит из двух частей: списочной и иллюстративной. Первая часть содержит перечень образных парадигм (характеризуется семантической связью опорных образных слов), внутри которой находятся образные ряды (лексикофразеологические ряды), каждый из которых скреплён единым образным словом (опорное слово). Вторая, иллюстративная, часть сло-

${ }^{1}$ Словарное описание образной лексики (языковые метафоры и метафорические дериваты) впервые было представлено в словаре М.И. Михельсона «Русская мысль и речь. Свое и чужое. Опыт русской фразеологии. Сборник образных слов и иносказаний» (1912), но не получило своего продолжения. В этом словаре наряду с фразеологизмами представлены образные слова, цитаты, пословицы, пословичные выражения, поговорки и изречения [25. С. 6-7]. 
варной статьи обеспечивает примерами образные парадигмы [23. C. 11, 15].

Кроме того, словарное описание образных средств языка может преследовать задачи концептуального лексикографического представления определённого фрагмента (или ряда фрагментов) образной системы языка, выраженного языковыми и речевыми средствами образного характера. Примером может служить «Словарь русской политической метафоры» А.Н. Баранова, Ю.Н. Караулова [24], в котором описываются метафорические номинации явлений политической сферы в публицистических текстах, распределённых в словаре по характеру общих и частных метафорических моделей. Отбор языкового материала в словарь обусловлен образным (метафорическим) характером номинаций представленной сферы внеязыковой действительности (сферы-мишени). В качестве источников для словаря составители использовали материалы съездов народных депутатов, политические дискуссии, отражённые в средствах массовой информации. «Словарь русских политических метафор» отличается построением макро- и микроструктур. Он разделён на две части: в первой представлен корпус метафорических контекстов, в которых политические реалии выступают сферой-мишенью для метафорических проекций, во второй - сферой-источником. Структура словарной статьи включает заглавное слово, называющее понятие, которое в политических текстах представлено метафорически. Вслед за заглавным словом приводится серия контекстов, демонстрирующих дискурсивную метафору. За поля словарной статьи вынесены номинации метафорических образов, через призму которых фигурально характеризуется толкуемое понятие. Таким образом, в словаре отсутствует принятая в традиционной лексикографии дефиниция, поскольку на первый план выходит демонстрация метафорических моделей.

Словарное описание единиц образной системы русского языка представляет языковое воплощение определённого культурного кода. Примером могут служить словари лингвокультурологического типа: «Русское культурное пространство» под ред. В.В. Красных [12]; Гудков Д.Б., Ковшова М.Л. «Телесный код русской культуры: материалы к словарю» [13], «Концептосфера русского языка: ключевые концепты и их репрезентации (на материале лексики, фразеологии и паремиологии): проспект словаря» под редакцией Л.Г. Бабенко 
[14]; Скляревская Г.Н. «Словарь православной церковной культуры» [15] и др. В лингвокультурологическом словаре «Русское культурное пространство» [12] представлены метафоры, прецедентные тексты, идиомы, описывающие функционирование образов животных в их языковых текстовых репрезентациях. По мнению авторов данного словаря, любой культурный концепт имеет в языке зону образного выражения, которую фиксирует лингвокультурологический словарь, представляющий образную лексику, фразеологию, паремиологию, отражающую интерпретацию толкуемых концептов культуры. Данный словарь авторы определяют как словарь «фиксирующего типа», который описывает то, что реально «знает» практически любой социализированный представитель русского национального лингвокультурного сообщества.

Следовательно, образные средства языка могут быть представлены в словарях в соответствии с такими дифференциальными признаками: 1. По структурному характеру образной языковой единицы. 2. По принципу комплексного описания образных средств языка, функционирующих в рамках языковой подсистемы (диалект, поэтический язык). 3. По принципу комплексного описания образной языковой репрезентации определённого фрагмента концептуальной системы: а) метафорического обозначения сферы-мишени; б) метафорического (образного) функционирования исходной сферы-донора.

Тенденции развития фигуративной лексикографии свидетельствуют о всё более детальной и глубокой проработке способов словарного изъяснения различных аспектов содержания толкуемых единиц. Современный словарь является не только собранием образных слов и/или выражений, он представляет собой продукт и отражение определенной научной концепции. Словари конца XX - начала XXI в., описывающие фрагменты образной системы языка, существенно отличаются от первых подобных лексикографических изданий. Во-первых, словарные статьи представляют результаты глубинного семантического анализа образных выражений с учётом их истории, этимологии, культурного фона и символического значения. Во-вторых, авторы опираются на огромные контекстные базы и обширные картотеки, созданные благодаря использованию машинного фонда и современных корпусных технологий. Это позволяет автоматизированно обрабатывать материал и проводить выборку необходимых единиц. 
Таким образом, виртуальное пространство фигуративной лексикографии включает создание фразеологических словарей (собственно фразеографию), словарей образных слов и выражений, образных сравнений, перифраз, пословиц и поговорок, поэтическую и лингвокультурологическую лексикографию, описывающую образное воплощение концептов и культурных кодов в языке. Составителями словарей, описывающих поэтические (А.И. Васильев, А.Л. Голованевский, Н.В. Павлович и др.), дискурсивные (А.Н. Баранов, Ю.Н. Караулов) и языковые метафоры (Г.Н. Скляревская и др.), фразеологический состав языка (А.Н. Баранов, Д.О Добровольский, А.В. Жуков, А.М. Мелерович, В.М. Мокиенко, В.Н. Телия и др.), пословицы, поговорки и крылатые фразы (Л.П. Дядечко, В.М. Мокиенко, С.Г. Шулежкова и др.); прецедентные феномены, образы и символы (Д.Б. Гудков, В.В. Красных и др.), были выработаны отдельные принципы лексикографического описания образных лексических и фразеологических единиц, но не были теоретически осмыслены и системно представлены. Решению данной задачи посвящен следующий раздел этой статьи.

\section{Принципы фигуративной лексикографии}

1. Принцип словарной презентации вторичных образных значений. Исходя из данного принципа, составители словарей, во-первых, определяют границы объекта лексикографирования, в качестве которого выступают слова и выражения, обладающие вторичными образными значениями метафорического, символического, перифрастического, иносказательного характера. В некоторых словарях учитывается тематика образного основания: в словаре Д.Б. Гудкова, М.Л. Ковшовой «Телесный код культуры» [13] объектом лексикографирования являются соматические фразеологизмы. В «Большом фразеологическом словаре русского языка» [4] толкуемые фразеологические единицы распределены в соответствии с семантикой выделенных авторами полей наивно-языковой картины мира, включающие в себя многообразие «кодов культуры». Для «Словаря устойчивых сравнений русского языка» [19] автор отобрал сравнения, имеющие антонимы и синонимы, и наиболее употребительные обороты, не входящие в синонимо-антонимические ряды. Во-вторых, данный принцип предполагает описание выбранного фрагмента образного строя русского языка в его целостности и системности. Авторы разрабатывают различные способы лексикографического пред- 
ставления фрагмента образной системы на уровне макроструктуры (систематизация по тематическим рубрикам, семантическим сферам, ключевому слову фразеологизма и т.п.) и дополнительных компонентов в структуре словарной статьи (изъяснение мотивирующего основания, презентация речевой трансформации, лингвокультурологические комментарии и др.). Это позволяет представить все многообразие информации, необходимой для правильной интерпретации лингвистических и экстралингвистических особенностей образной лексики и фразеологии. Например, в «Словаре образных слов и выражений сибирского говора» [17] образная лексика и фразеология представлены в их семантическом единстве. «Словарь-тезаурус русских пословиц, поговорок и метких выраженний» [21] включает пословицы, поговорки, молвушки, присловия, приговорки, присказки, загадки, приметы, дразнилки и считалки.

2. Экспликация мотивирующего компонента образной единицы. Образное основание формирует важнейшую часть семантики, поэтому его разъяснение необходимо, с одной стороны, для толкования значения лексикографируемой единицы (О.И. Блинова, М.Л. Ковшова, А.М. Мелерович, В.М Мокиенко, В.Н. Телия, Е.А. Юрина и др.), раскрытия глубинной семантики и характера образной аналогии, выявления метафорических моделей, выводимых из семантики образных единиц. С другой стороны, раскрытие внутренней формы образных слов и выражений объясняет особенности употребления образных единиц, их сочетаемость. В «Словаре образных слов русского языка» [16] представлено изъяснение мотивирующего основания образной номинации. Во «Фразеологическом объяснительном словаре русского языка» [3] поясняется образный компонент в той степени, в которой влияет на актуальное значение и позволяет реконструировать сам образ. Данный принцип реализован в современных словарях, являющихся ядром фигуративной лексикографии.

3. Разъяснение закреплённых за образными словами и выражениями экспрессивных и эмотивных коннотаций. Реализация данного принципа позволяет показать основные функциональностилистические и семантические различия и особенности, характерные для образных единиц. Традиционно в словарях используются эмоционально-оценочные и экспрессивные пометы, например: бран. - бранное, ирон. - ироническое, ласк. - ласкательное (А.Н. Ба- 
ранов, Д.О. Добровольский, А.М Мелерович, В.М. Мокиенко) и др. Но для более полного и разноаспектного анализа семантики образных слов и выражений авторы «Большого фразеологического словаря русского языка» [4] отказались от помет и выделили эмоционально-оценочное отношение говорящего в отдельную подзону словарной статьи: в зонах толкований и иллюстраций обозначены грамматические и стилистические запреты на высказывания о третьем лице, о собеседнике или о самом говорящем.

4. Раскрытие культурного содержания. За образными словами и выражениями закрепляются культурный фон и культурная коннотация, которые способствуют погружению в пространство культуры: при употреблении образных слов и выражений носителем языка осознается не только образ, лежащий в основе таких единиц языка, но и культурная информация, ассоциативно связанная с образом. Прояснение культурно-символического содержания (обрядовый, ритуальный, мифологический, сакральный смыслы; общекультурные сведения) дает возможность для более глубокого семантического анализа. На практике этот принцип реализуется в форме лингвокультурологического комментария или культурно-исторической справки (А.Н. Баранов, Д.О. Добровольский, М.Л. Ковшова, В.Н. Телия и др.). Целью историко-этимологического комментария в словаре «Фразеологизмы в русской речи» [7] стало выявление исходной мотивировки фразеологизма как источника всех зафиксированных позднейших трансформаций. Фразеологизмы в «Большом фразеологическом словаре русского языка» [4] рассматриваются авторами как знаки языка культуры, поэтому в словарную статью введен лингвокультурологический комментарий, раскрывающий взаимодействие языка и культуры. «Словарь-тезаурус русских пословиц, поговорок и метких выражений» [21] содержит исторические и лингвострановедчекие комментарии, этимологические справки для разъяснения непонятных слов, историзмов и диалектизмов. Практически все словари, интерпретирующие в лексикографической форме образный лексический и фразеологический фонд, являются лингвокультурологическими либо по цели толкования, либо по возможности использования их в качестве источника лингвокультурологических исследований.

5. Принцип ориентации на функционирование образных средств языка в речи, учёт речевого узуса. Иллюстративный материал позво- 
ляет более полно толковать образные единицы, выявлять разнообразные смысловые оттенки, возможные трансформации и выделять ситуации употребления. В словаре «Фразеологизмы в русской речи» [7] представлены разнообразные трансформированные употребления фразеологических единиц, включены индивидуально-авторские употребления фразеологизмов. Иллюстративный материал в «Словаре устойчивых сравнений русского языка» [19] отражает вариантные, факультативные и подвижные компоненты и диапазон объектов речевого приложения сравнений.

6. Концептуальная организация макроструктуры словаря. Образная лексика и фразеология диктуют необходимость особого расположения материала, отражающего структурно-семантические связи единиц и единство метафорического образа. Например, в «Большом фразеологическом словаре русского языка» [4] фразеологизмы сгруппированы в образно-смысловые гнёзда, внутри которых образные выражения расположены в алфавитном порядке, это объясняется тем, что фразеологизмы вне словарной презентации образуют семантические гнезда. «Словарь поэтических образов» [22] состоит из 23 больших тематических разделов, каждый из которых включает более мелкие рубрики. В «Словаре устойчивых сравнений русского языка» [19] принят алфавитно-гнездовой принцип подачи материала. Гнездо включает образные сравнения, объединенные общим субъектом сравнения, а уже гнезда располагаются в алфавитном порядке. «Словарь-тезаурус русских пословиц, поговорок и метких выражений» [21] состоит из 47 глав, организованных по тематическому принципу. Сам материал представлен как рассказ-объяснение, как диалог с читателем, комментарии к которому дает автор.

Таким образом, представленные в обзоре словари различаются по типу объекта, целям и задачам, при этом прослеживается общая тенденция в принципах и подходах к лексикографированию образных средств языка, проявляющаяся, во-первых, в особой концепции макроструктуры словаря (отход от алфавитной подачи в направлении к различного типа смысловой рубрикации, отражающей структурно-семантические связи); во-вторых, в более подробной и полной семантизации толкуемых единиц с учётом лингвистических и экстралингвистичеких факторов. 


\section{Лексикографическая презентация фрагмента общеязыковой образной системы}

В основе концептуального лексикографического описания образных средств языка, вербализующих базовые и частные метафорические модели, лежит положение о системности языковых образов, представленных в разных вариантах в трудах отечественных и зарубежных лингвистов. Наибольшей популярностью пользуется когнитивная теория метафоры Дж. Лакоффа и М. Джонсона, получившая признание, критическое осмысление и развитие в работах Р. Гиббса, Ж .Фоконье и М. Тёрнера, В. Эванса, А.Н. Баранова, Д.О. Добровольского, В.Н. Телия, А.П. Чудинова и др. В рамках когнитивного подхода метафора понимается как смысловая модель, по которой осуществляется мышление по аналогии, т.е. одна концептуальная область описывается языковыми единицами другой концептуальной области [2. С. 18]. В семасиологическом и лингвостилистическом ключе идеи системной организации образно-символического лингвоконцептуального кода представлены в теории лексикофразеологической образности (Н.Ф. Алефиренко, О.И. Блинова, Н.А. Илюхина, С.М. Мезенин, Г.Н. Скляревская, Е.А, Юрина и др.). Согласно этой теории образность определяется как языковая функционально-семантическая категория, имеющая семантическую основу (двуплановость значения) и средства её выражения (метафорическая внутренняя форма слова). По определению Е.А. Юриной, образный строй языка понимается как «закреплённая в узусе национально и культурно обусловленная система образов, метафорически реализованная в семантике лексических и фразеологических единиц языка и формирующая языковую картину мира его носителей» [2. С. 19]. Образный строй языка, с одной стороны, - это системное лингвистическое явление, имеющее семантический уровень и знаковую форму выражения. С другой - когнитивные структуры, входящие в систему представлений языковой личности, на которых базируются языковые способности к образному ассоциированию, реализуемые в речевой деятельности [Там же].

Объектом словарного описания в рамках фигуративной лексикографии может выступать тот или иной фрагмент образной системы русского языка. Идея составления «Словаря русской пищевой метафоры» [1] зародилась в контексте бурного развития фигуративной лексикографии в начале XXI в. и была подготовлена имеющимся в 
томской лингвистической школе опытом создания словарей образных слов и выражений русского литературного языка [16] и народных говоров [17]. Структура данного словаря разработана с опорой на выделенные принципы фигуративной лексикографии, которые были отрефлексированы в процессе практической работы по его созданию. Концепция складывалась индуктивно: от практики составления словаря к последующему теоретическому обоснованию принципов и способов его создания.

«Словарь русской пищевой метафоры» является первым в отечественной лингвистике словарём, который представляет систему образных средств русского языка, отражающих метафорические проекции из сферы «Еда» в различные понятийные области. Объектом лексикографирования являются образные средства русского языка, называющие различные явления окружающего мира по аналогии с продуктами питания и блюдами русской национальной кухни. Данный фрагмент образной системы был избран в качестве объекта лексикографирования в силу высокой метафорической активности кулинарии как исходной сферы-донора, что проявилось в большом количестве лексико-фразеологических средств (3550 единиц), а также высокой частотности употреблений в разных типах дискурса (о чём свидетельствуют данные Национального корпуса русского языка). Важной задачей составителей является отражение системности описываемого фрагмента образного строя языка с точки зрения сохранения единства исходных образов, иносказательно выражающих представления носителей русского языка о различных явлениях внеязыковой действительности.

Вербальными единицами представленного фрагмента образной системы языка являются образные слова и выражения, в числе которых языковые метафоры (ЯМ): посудина 'о громоздком или неисправном водном или воздушном судне'; собственно образные слова (СО): чашевидный 'о бутонах цветов, напоминающих по форме чашу’; двухкомпонентные образные номинации (ОН): глазное яблоко 'анатомический термин, называющий глаз'; сравнения с компаративным элементом как, словно, будто (В сравн.): как горох 'о мелких предметах, изображениях'; родительный сравнения (Род. сравн.): цвета соли с перцем 'о тёмных волосах, перемешанных с седыми или осветленными прядями'; творительный сравнения (Твор. сравн.): костью в горле 'досаждающим препятствием, неприятным явлением'; 
фразеологические единицы (ФЕ): дать / задать перцу 'отругать, отчитать кого-л. за серьёзный проступок, устроить скандал'; пословицы (Посл.): на халяву и уксус сладкий 'то, что достается без усилий, бесплатно, принимается без претензий, не оценивается критически'; поговорки (Погов.): остатки сладки 'даже последняя малая часть чего-л. имеет ценность'. Концептуальными единицами выбранного фрагмента образной системы языка являются типовые образные представления - частные метафорические модели, выводимые из семантики целого ряда образных единиц языка, для которых характерно единство исходного мотивирующего образа, денотата образной номинации и основания метафорической проекции.

«Словарь русской пищевой метафоры» состоит из трёх томов: «Блюда и продукты питания», «Гастрономическая деятельность», «Образ мира в зеркале пищевой метафоры». Первые два тома составлены по тематике исходной сферы-источника метафорических проекций и демонстрируют метафорическое функционирование гастрономических образов. Третий том построен по идеографическому принципу, демонстрирующему сферы-мишени метафорических проекций. Расположение материала в первом и втором томах данного словаря строится по тематическому, гнездовому и алфавитному (внутри гнезда) принципам, например: 1. Продукты растительного происхождения: 1.1. Зерновые продукты, мучные и крупяные изделия. 1.2. Фрукты. 1.3. Овощи. 1.4. Ягоды. 1.5. Грибы. 1.6. Орехи. В каждом подразделе представлены лексико-фразеологические гнезда, вершиной которых выступает исходная гастрономическая номинация. Такая макроструктура словаря позволяет системно представить фрагмент образного строя русского языка, связанный с метафорическим, образным и символическим переосмыслением вещного мира, социальной и политической жизни, экономических процессов, эмоций.

Словарная презентация лексико-фразеологического гнезда включает: I. Толкование исходного значения мотивирующей единицы, например: мука 'рассыпчатый продукт питания белого цвета, получаемый путём перемалывания зёрен различных культур, измельчённых до порошкообразного состояния; в основном применяется при приготовлении хлебобулочных изделий'. II. Толкование образных значений, представленных единицами лексикофразеологического гнезда. Например: мука (ЯМ) 'что-л. измельчен- 
ное до порошкообразного состояния'; как мука (В сравн.) 'о чем-л. рассыпчатом, порошкообразном, напоминающем по структуре муку', 'о чем-л. бледного, серовато-белого изета'; [всё] перемелется мука будет (Посл.) 'тяжелые времена пройдут, и все будет хорошо. Говорится человеку, чтобы его успокоить’. III. Лингвокультурологический комментарий (подробнее см.: [33]). Первый том включает 168 лексико-фразеологических гнёзд, объединяющих 1705 лексикосемантических вариантов образных слов и выражений, второй том 104 гнезда, 1845 толкуемых единиц. IV. Толкование типовых образных представлений. Формулировки типовых образных представлений в «Словаре русской пищевой метафоры» репрезентируют модель и ценностно-понятийные основания уподобления определенного концепта из гастрономической сферы концептам из других понятийных сфер. Например, представления, связанные с метафорической проекцией образа муки, описаны в словаре следующим образом: 1. Серовато-белая мука выступает образным эталоном для характеристики предметов подобного цвета. 2. Образ муки, измельченной до порошкообразного состояния, проецируется на сыпучие или рыхлые вещества аналогичной структуры. 3. Процесс размалывания зерна в муку ассоциативно связывается с преодолением жизненных трудностей для получения положительных результатов [1. C. 57].

Таким образом, представленные в статье результаты анализа различных по типу и структуре словарей образных слов и выражений свидетельствуют, что фигуративная лексикография является актуальным направлением современной русистики. Это подтверждают количественный состав вышедших за последние двадцать лет словарей, описывающих образный фонд русской речи (более 30), их типологическое и содержательное разнообразие, концептуальный принцип организации, широкий охват лексикографируемого языкового и дискурсивного материала, глубина семантического и культурологического анализа, содержащегося в изъяснении семантики. В качестве основных тенденций фигуративной лексикографии можно выделить следующие: расширение фокуса толкования за счёт толкования образной составляющей; усложнение структуры словарной статьи путём введения новых рубрик, например функциональносемантической характеристики фразеологических единиц, лингвокультурологического комментария, указание метафорической моде- 
ли, истолкование типового образного представления; добавление разнообразных комментариев и помет; интегративный характер описания, включающий помимо подробного толкования семантики сведения из области этимологии, истории языка, культуры и др.; комплексное лексикографирование различных образных средств языка, объединенных общностью исходной мотивирующей и/или предметно-понятийной семантики.

\section{Литература}

1. Словарь русской пищевой метафоры. - Т. 1: Блюда и продукты питания / под ред. Е.А. Юриной. - Томск: Изд-во Том. ун-та, 2015. - 428 с.

2. Юрина Е.А. Вкусные метафоры: пищевая традиция в зеркале языковых образов. - Кокчетав: Келешек, 2013. $-238 \mathrm{c}$.

3. Баранов А.Н., Добровольский Д.О. Фразеологический объяснительный словарь русского языка. -М.: Эксмо, 2009. - 704 с.

4. Большой фразеологический словарь русского языка: Значение. Употребление. Культурологический комментарий / отв. ред. В.Н. Телия. - 4-е изд. - М.: АСТПРЕСС, 2009. - 784 c.

5. Бирих А.К., Мокиенко В.М.,. Степанова Л.И. Словарь фразеологических синонимов русского языка / под ред. В.М. Мокиенко. - М.: АСТ-ПРЕСС КНИГА, 2009. $-448 \mathrm{c}$.

6. Фразеологический словарь русского литературного языка конца XVIIIXX вв: в 2 т. / сост. А.И. Федоров. - Новосибирск: Наука. Сиб. изд. фирма РАН, 1995.

7. Мелерович А.М., Мокиенко В.М. Фразеологизмы в русской речи: слов. - М.: Русские словари, 1997. -864 с.

8. Жуков А.В., Жукова М.Е. Современный фразеологический словарь русского языка. - М.: АСТ-Пресс, 2009. - 443 с.

9. Жуков А.В., Жукова М.Е. Словарь современной русской фразеологии. - М.: АСТ-Пресс, 2015. $-416 \mathrm{c}$.

10. Алефиренко Н.Ф., Золотых Л.Г. Фразеологический словарь: Культурнопознавательное пространство русской идиоматики. - М.: Элпис, 2008. -472 с.

11. Фразеологический словарь русского языка: св. 4000 словарных статей / под ред. А.И. Молоткова. -3-е изд., стер. - М.: Рус. яз., 1978. - 543 с.

12. Русское культурное пространство: Лингвокультурологический словарь: Вып. 1: (Зооморфные образы) / И.С. Брилева, Н.П. Вольская, Д.Б. Гудков, И.В. Захаренко, В.В. Красных. - М.: Гнозис, 2004. -318 с.

13. Гудков Д.Б., Ковшова М.Л. Телесный код русской культуры: материалы к словарю. - М..: Гнозис, 2007. -288 с.

14. Конщептосфера русского языка: ключевые концепты и их репрезентации (на материале лексики, фразеологии и паремиологии): проспект словаря / под общ. ред. Л.Г. Бабенко. -Екатеринбург: Изд-во Урал. ун-та, 2010. -340 с.

15. Скляревская Г.Н. Словарь православной церковной культуры. - М.: АСТ: Астрель, 2008. - 480 с. 
16. Блинова О.И., Юрина Е.А. Словарь образных слов русского языка. - Томск: UFO-Plus, 2007. - 364 c.

17. Словарь образных слов и выражений народного говора / под ред. О.И. Блиновой. - Томск: Изд-во Том. ун-та, 2001. -312 с.

18. Словарь образных выражений русского языка / Т.С. Аристова, М.Л. Ковшова, Е.А. Рысева и др.; под ред. В.Н. Телия. - М.: Отечество, 1995. - 368 с.

19. Огольцев B.M. Словарь устойчивых сравнений русского языка (синонимоантонимический). - М.: ООО «Русские словари»: ООО «Изд-во Астрель»: ООО «Изд-во АСТ», 2001. -800 с.

20. Жуков В.П. Словарь русских пословиц и поговорок. - М.: Рус. яз., 2000. $544 \mathrm{c}$.

21. Зимин В.И. Словарь-тезаурус русских пословиц, поговорок и метких выражений. - М.: АСТ-Пресс, 2008. - 729 с.

22. Павлович Н.В. Словарь поэтических образов: в 2 т. - М.: Эдиториал УРСС, 1999. $-848 \mathrm{c}$.

23. Иванова Н.Н., Иванова О.Е. Словарь языка поэзии (образный арсенал русской лирики конца XVIII - начала XX в.): Более 4500 образных слов и выражений. М.: ООО «Изд-во АСТ»: ООО «Изд-во Астрель»: ООО «Изд-во «Русские словари»: ООО «Транзиткнига», 2004. -666 с.

24. Баранов А.Н., Караулов Ю.Н. Словарь русских политических метафор. - М.: Помовский и партнеры, 1994. - 330 с.

25. Михельсон М.И. Русская мысль и речь. Свое и чужое: Опыт русской фразеологии: сб. образных слов и иносказаний. -СПб., 1912.

26. Юрина E.A. Мотивологические основы теории лексической образности // Актуальные проблемы мотивологии в лингвистике XXI в. - Томск, 2012. - С. 129144.

27. Блинова О.И., Юрина Е.А. Образная лексика русского языка // Язык и культура. - Томск, 2008. - №1. - С. 5-13.

28. Юрина E.A. Образный строй языка. Томск: Изд-во Том. ун-та, 2005. - 153 с.

29. Ковшова М.Л. Вероника Николаевна Телия [Электронный ресурс] // Фразеологический семинар проф. В.М. Мокиенко. - Электрон. дан. - [Б. м.], 2011. - URL: http://phraseoseminar.slovo-spb.ru/telia.htm (дата обращения: 30.01.2016).

30. Скляревская Г.Н. Языковая метафора в толковом словаре: Проблемы семантики. - М.: Препринт АН СССР. Ин-т рус. яз., 1988. - 58 с.

31. Шенделева (Юрина) E.A. Образное слово в словаре (на материале русского литературного языка) // Проблемы лексикографии, мотивологии, дериватологии. Томск, 1998. С. 106-116.

32. Блинова О.И. Образное слово в толковом словаре // Актуальные проблемы разработки нового академического словаря русского языка: тез. докл. - Л., 1990. C. $115-117$.

33. Юрина Е.А., Грекова М.В. Культурологический комментарий в «Словаре русской кулинарной метафоры» (на материале тематической группы «Молочные продукты») // Язык и культура. - Томск, 2014. - № 4(28). - С. 126-144. 


\section{FIGURATIVE LEXICOGRAPHY AND ITS PLACE IN MODERN RUSSIAN PHI- LOLOGY}

Voprosy leksikografii - Russian Journal of Lexicography, 2016, 2(10), pp. 18-40. DOI: $10.17223 / 22274200 / 10 / 2$

Marina V. Grekova, Tomsk State University (Tomsk, Russian Federation). E-mail: marinagrekova@gmail.com

Keywords: figurative lexicography, cultural linguistic dictionary, figurative units, food metaphor.

The purpose of this article is to determine the composition, volume, borders, features of figurative lexicography as a special direction of Russian studies on the compiling of dictionaries that describe secondary nomination with figurative meanings. This aim is due to the necessity of solving a number of applied problems related to the practical work on the creation of The Dictionary of Russian Food Metaphor, the first volume of which, Dishes and Foodstuff, has already been published, the second volume, Culinary Activities, is being prepared for publishing. However, many of the problems of the conceptual organization of the material and its semantization require theoretical understanding and scholarly coverage.

Figurative lexicography is a special trend in Russian studies which is engaged in the preparation and study of dictionaries that fix the figurative fund of the Russian language. The object of figurative lexicography is dictionaries, diverse in purpose and structure, united by the figurative character of descriptions of units that have a metaphorical inner form and express the allegorical, figurative way to represent thoughts or ideas. These lexicographical works include phraseological and cultural linguuistic dictionaries, dictionaries of figurative words and phrases, proverbs and sayings, poetic images, discursive metaphors. Authors of dictionaries that describe the poetic (A.I. Vasiliev, A.L. Golovanevskiy, N.V. Pavlovich etc.), discursive (A.N. Baranov, Yu.N. Karaulov) and language (G.N. Sklyarevskaya etc.) metaphors, the phraseological fund (A.N. Baranov, D.O. Dobrovolsky, A.V. Zhukov, A.M. Melerovich, V.M. Mokienko, V.N. Telia etc.), proverbs, sayings and catch phrases (L.P. Dyadechko, V.M. Mokienko, S.G. Shulezhkova etc.); precedent phenomena, images and symbols (D.B. Gudkov, V.V. Krasnych etc.) worked out some principles of lexicographical description of figurative lexical and phraseological units, but they have not been theoretically conceptualized and systematically presented.

The principles of figurative lexicography are: 1 . The principle of dictionary presentation of secondary figurative meanings. 2. Explication of the motivating component of a figurative unit. 3. Explanation of expressive and emotive connotations assigned to figurative words and expressions. 4. Representation of the cultural content. 5. Orientation on the functioning of figurative units in speech. 6. Conceptual organization of the dictionary macrostructure.

The structure of the Dictionary of Russian Food Metaphor is based on the outlined principles of figurative lexicography which were reflected in the practical work on its creation. This dictionary is the first dictionary in the national linguistics to present a system of figurative units of the Russian language that reflect the metaphorical projection from the sphere "Food" in a variety of conceptual areas. The object of lexicographying is figurative units of the Russian language that name various phenomena of the world by analogy with food and dishes of Russian national cuisine. 


\section{References}

1. Yurina, E.A. (ed.) (2015) Slovar' russkoy pishchevoy metafory [Dictionary of Russian food metaphor]. Vol. 1. Tomsk: Tomsk State University.

2. Yurina, E.A. (2013) Vkusnye metafory: pishchevaya traditsiya v zerkale yazykovykh obrazov [Delicious metaphors: food tradition in the mirror of language images]. Kokshetau: Keleshek.

3. Baranov, A.N. \& Dobrovol'skiy, D.O. (2009) Frazeologicheskiy ob"yasnitel'nyy slovar' russkogo yazyka [Phraseological explanatory dictionary of the Russian language]. Moscow: Eksmo.

4. Teliya, V.N. (ed.) (2009) Bol'shoy frazeologicheskiy slovar' russkogo yazyka. Znachenie. Upotreblenie. Kul'turologicheskiy kommentariy [Big phraseological dictionary of the Russian language. Meaning. Use. Culturological commentary]. 4th ed. Moscow: AST-PRESS.

5. Birikh, A.K., Mokienko, V.M. \&. Stepanova, L.I. (2009) Slovar' frazeologicheskikh sinonimov russkogo yazyka [Dictionary of phraseological synonyms of the Russian language]. Moscow: AST-PRESS KNIGA.

6. Fedorov, A.I. (1995) Frazeologicheskiy slovar' russkogo literaturnogo yazyka kontsa XVIII - XX vv: $v 2 t$. [Phraseological dictionary of the Russian literary language of the late 18th-20th centuries: in 2 vols]. Novosibirsk: Nauka, Sibirskaya izdatel'skaya firma RAN.

7. Melerovich, A.M. \& Mokienko, V.M. (1997) Frazeologizmy v russkoy rechi. Slovar' [Idioms in the Russian language. A dictionary]. Moscow: Russkie slovari.

8. Zhukov, A.V. \& Zhukova, M.E. (2009) Sovremennyy frazeologicheskiy slovar' russkogo yazyka [Modern phraseology dictionary of Russian]. Moscow: AST-Press.

9. Zhukov, A.V. \& Zhukova, M.E. (2015) Slovar' sovremennoy russkoy frazeologii [Dictionary of modern Russian phraseology]. Moscow: AST-Press.

10. Alefirenko, N.F. \& Zolotykh, L.G. (2008) Frazeologicheskiy slovar': Kul'turnopoznavatel'noe prostranstvo russkoy idiomatiki [Phraseology dictionary: Culturalcognitive space of Russian idioms]. Moscow: Elpis.

11. Molotkov, A.I. (ed.) (1978) Frazeologicheskiy slovar' russkogo yazyka: Svyshe 4 000 slovarnykh statey [Phraseology dictionary of Russian language: Over 4000 entries]. 3rd ed. Moscow: Russkiy yazyk.

12. Brileva, I.S. et al. (2004) Russkoe kul'turnoe prostranstvo: Lingvokul turologicheskiy slovar' [Russian cultural space: a linguoculturological dictionary]. Vol. 1. Moscow: Gnozis.

13. Gudkov, D.B. \& Kovshova, M.L. (2007) Telesnyy kod russkoy kul'tury: materialy $k$ slovaryu [The body code of Russian culture: materials for a dictionary]. Moscow: Gnozis.

14. Babenko, L.G. (ed.) (2010) Kontseptosfera russkogo yazyka: klyuchevye kontsepty $i$ ikh reprezentatsii (na materiale leksiki, frazeologii i paremiologii): prospekt slovarya [The concept sphere of the Russian language: key concepts and their representation (based on the vocabulary, phraseology and paremiology): prospect of a dictionary]. Ekaterinburg: Ural State University.

15. Sklyarevskaya, G.N. (2008) Slovar' pravoslavnoy tserkovnoy kul'tury [Dictionary of the Orthodox church culture]. Moscow: AST: Astrel'.

16. Blinova, O.I. \& Yurina, E.A. (2007) Slovar' obraznykh slov russkogo yazyka [Dictionary of figurative words of the Russian language]. Tomsk: UFO-Plus. 
17. Blinova, O.I. (ed.) (2001) Slovar' obraznykh slov $i$ vyrazheniy narodnogo govora [Dictionary of figurative words and expressions of a folk dialect]. Tomsk: Tomsk State University.

18. Teliya, V.N. (ed.) (1995) Slovar' obraznykh vyrazheniy russkogo yazyka [Dictionary of figurative words of the Russian language]. Moscow: Otechestvo.

19. Ogol'tsev, V.M. (2001) Slovar' ustoychivykh sravneniy russkogo yazyka (sinonimo-antonimicheskiy) [Dictionary of set comparisons of the Russian language (synonyms \& antonyms)]. Moscow: Russkie slovari: Astrel': AST.

20. Zhukov, V.P. (2000) Slovar' russkikh poslovits i pogovorok [Dictionary of Russian proverbs and sayings]. Moscow: Russkiy yazyk.

21. Zimin, V.I. (2008) Slovar'-tezaurus russkikh poslovits, pogovorok i metkikh vyrazheniy [The dictionary-thesaurus of Russian proverbs, sayings and apt expressions]. Moscow: AST-Press.

22. Pavlovich, N.V. (1999) Slovar' poeticheskikh obrazov. V 2-kh $t$. [Dictionary of poetic images. In 2 vols]. Moscow: Editorial URSS.

23. Ivanova, N.N. \& Ivanova, O.E. (2004) Slovar' yazyka poezii (obraznyy arsenal russkoy liriki kontsa XVIII - nachala XX v.): Bolee 4500 obraznykh slov $i$ vyrazheniy [Dictionary of poetry language (the figurative arsenal of Russian lyrics of the late 18th early 20th centuries): More than 4,500 figurative words and phrases]. Moscow: AST: Astrel': Russkie slovari: Tranzitkniga.

24. Baranov, A.N. \& Karaulov, Yu.N. (1994) Slovar' russkikh politicheskikh metafor [Dictionary of Russian political metaphors]. Moscow: Pomovskiy i partnery.

25. Mikhel'son, M.I. (1912) Russkaya mysl' i rech'. Svoe i chuzhoe. Opyt russkoy frazeologii. Sbornik obraznykh slov i inoskazaniy [Russian thought and speech. Own and alien. Experience of Russian phraseology. Collection of figurative words and parables]. St. Petersburg.

26. Yurina, E.A. (2012) Motivologicheskie osnovy teorii leksicheskoy obraznosti [Motivological bases of the theory of lexical imagery]. Aktual'nye problemy motivologii $v$ lingvistike XXI v. [Topical issues of linguistics in the 21st century]. Proceedings of a conference. Tomsk: Tomsk State University. pp. 129-144. (In Russian).

27. Blinova, O.I. \& Yurina, E.A. (2008) Obraznaya leksika russkogo yazyka [The figurative vocabulary of the Russian language]. Yazyk i kul'tura - Language and Culture. 1. pp. $5-13$.

28. Yurina, E.A. (2005) Obraznyy stroy yazyka [The imagery of the language]. Tomsk: Tomsk State University.

29. Kovshova, M.L. (2011) Veronika Nikolaevna Teliya. [Online] Available from: http://phraseoseminar.slovo-spb.ru/telia.htm. (Accessed: 30th January 2016).

30. Sklyarevskaya, G.N. (1988) Yazykovaya metafora v tolkovom slovare: Problemy semantiki [Language metaphor in thesauruses: Problems in semantics]. Moscow: Preprint AN SSSR. In-t rus. yaz.

31. Shendeleva (Yurina), E.A. (1998) [Figurative word in the dictionary (on the material of the Russian literary language)]. Problemy leksikografii, motivologii, derivatologii [Problems of lexicography, motivology, word formation]. Proceedings of the conference. Tomsk: Tomsk State University. pp. 106-116. (In Russian).

32. Blinova, O.I. (1990) [Figurative word in an explanatory dictionary]. Aktual'nye problemy razrabotki novogo akademicheskogo slovarya russkogo yazyka [Topical issues of 
the development of a new academic dictionary of the Russian language]. Proceedings of the conference. Leningrad. pp. 115-117. (In Russian).

33. Yurina, E.A. \& Grekova, M.V. (2014) Culturological commentary in "Russian dictionary of culinary metaphors" (based on the thematic group "dairy products"). Yazyk $i$ kul'tura - Language and Culture. 4(28). pp. 126-144. (In Russian). 